\title{
From the memory of history: Evagrius Ponticus and his writings in the preoccupations of Patriarch Iustin Moisescu
}

\author{
Assist. Prof. PhD Florin VÂRLAN \\ Faculty of Theology and Sciences of Education, \\ Valahia University of Târgovişte, \\ ROMANIA \\ E-mail: varlanflorin@yahoo.com
}

\begin{abstract}
The year 2019 was dedicated to paying homage to one of the foremost servants of the Romanian Orthodox Church - patriarch Iustin Moisescu. This was a good opportunity for us to bring back to light writings which relate to his preoccupations with the teachings of the Church Fathers. These preoccupations originate as early as the time of the courses attended in the "Miron Patriarhul" Seminary in Câmpulung Muscel, which he graduates as valedictorian, followed by the Faculty of Theology in Athens, where he goes for four years, between October 1930 and July 1934. Following this fruitful period, he prepares his doctoral thesis entitled "Evagrius Ponticus. Life, Writings and Teachings" which he presents in 1937 in Athens, under the guidance of the distinguished Greek patrologist Dimitrios Balanos. This paper was graded as exceptional.
\end{abstract}

Keywords: Evagrius Ponticus; patristic research; ascetic writings.

\section{INTRODUCTION}

In a study dedicated to patriarch Iustin Moisescu, Professor Priest Nicolae C. Buzescu characterizes the doctoral thesis as "a locked treasure, accessible only to specialists in classical languages or theologists who are better acquainted to them"1. Despite the fact that it conveys the idea that the paper is "locked", in other words it does not target the general public, this assertion encompasses yet a "treasure" of information and ideas regarding Christian life, as he discovered it in the writings of Evagrius Ponticus.

According to the same illustrious professor, "the paper falls under the category of strict literature, expression of an impressive erudition and a great power of theological and philosophical summarization. It is the result of a vast patristic research in which are used all works consecrated to Evagrius Ponticus until 1937"2.

The reason of having chosen this theme is disclosed by the author himself, who published in Romanian, no later than one year after its presentation, an ample summary of this thesis in which we find the assertion that Evagrius Ponticus is the most important and original personality of the Orthodoxy, "the father of the Byzantine asceticism and mysticism", as "the whole spiritual teachings of the Eastern Church" ${ }^{3}$ nowadays originate in his writings.

\footnotetext{
${ }^{1}$ Pr. prof. dr. N.C. Buzescu, Preocupări patristice ale Prea Fericitului Patriarh Iustin, în rev. Mitropolia Olteniei, No. 3-4/1980, p. 315.

${ }^{2}$ Ibid, p. 316.

${ }^{3}$ Dr. Iustin Moisescu, Evagrie din Pont, în rev. Biserica Ortodoxă Română, No. 5-6/1938, p. 230.
} 


\section{BIBLIOGRAPHIC DATA ON EVAGRIUS PONTICUS}

When presenting Evagrius Ponticus' life, writings and teachings, patriarch Iustin uses as Bibliography 74 titles of papers. For Evagrius' life, use was made of: "The Lausiac History, written by Palladius, bishop of Helenopolis in Bithynia, his friend and disciple; History of the Monarchs in Egypt, paper written at the beginning of the $5^{\text {th }}$ century and kept in Rufin's Latin translation; and the works of church history by Socrates and Sozomen, Ieronymos and Gennadius"4.

For that reason, we find written records of Evagrius being born in $345^{5}$ in Ibora of Pontus (therefore the pseudonym of "Ponticus"6). His father, who was a country bishop, was a very close friend of the Saints Basil the Great and Gregory of Nazianzus. It is even assumed that young Evagrius was taught by Saint Gregory ${ }^{7}$, from whom he had the chance to acquire excellent theological knowledge, and much more, which led him to choose an ascetic life. So it is that Evagrius grows as a Christian and becomes "disciple of the great teachers of Church, who instilled in him both the living faith in God and the passion for the hermit lifestyle. He distinguished himself by a life led in virtue and his great knowledge acquired as a young boy" ${ }^{\prime 8}$.

In an epistle written in 369 by Saint Gregory of Nazianzus for the father of his disciple, whose name was also Evagrius, the author shows his satisfaction with the educational motivation of his disciple and praises him for having acquired as a young man "the fear of God and the conviction to despise the things of the present world"9.

While spending his life with the Saints of Cappadocia, away from the world, Evagrius learns the dogma of the Church, explains the Holy Scripture with his teachers and contributes to preparing the Philokalia starting from Origen's works. In the meantime, he reads the writings and feels passionate about the theological system of the great didascal of Alexandria, to whom he continues to feel great affection, being condemned for Origenism at the $5^{\text {th }}$ Ecumenical Council. This will lead to the disappearance of his works written in Greek, (only Syrian and Armenian translations being kept), namely to monophysite Christians or under other names such as the one of Nil the Hermit. ${ }^{10}$

Evagrius continues to stand by Saint Basil the Great who ordains him as lector. When the latter passes away, he decides to leave Cappadocia and follows Saint Gregory the Theologian who promotes him as deacon. Following this promotion, he accompanies Saint Gregory to Constantinople where he participates to the second Ecumenical Council. After

\footnotetext{
${ }^{4}$ Pr. Prof. Ștefan Alexe, Sfinții Părinți în preocupările Prea Fericitului Patriarh Iustin, în rev. Biserica Ortodoxă Română, No. 3-4/1985, p. 267.

${ }^{5}$ We chose year 345 , as a certain date of his birth, as recorded by hieromonk Gabriel Bunge, the most tenacious researcher of Evagrius' work (see vezi Ieromonah Gabriel Bunge, Akedia. Plictiseala și terapia ei după avva Evagrie Ponticul, trad. Ioan I. Ică jr., Ed. DEISIS, Sibiu, 1999, p. 27; and also Evagrie Ponticul. Scolii la Pilde și Ecclesiast, trad. de ieromonah Agapie Corbu, Editura Institutului Biblic şi de Misiune Ortodoxă, București, 2017, p. 9, data taken over by Paladie, Istoria lausiacă, trad. de pr. prof. dr. D. Stăniloae, Editura Institutului Biblic şi de Misiune a Bisericii Ortodoxe Române, București, 2007, p. 87, where we are told that "he passed away at the age of fifty-four, away from the world", i.e. in 399 and not 346, as we may find in the work of patriarch Iustin Moisescu.

${ }^{6}$ Pr. Prof. Dr. Ioan G. Coman, Patrologie, Ed. Mănăstirii Dervent,2000, p. 141.

${ }^{7}$ Ieromonah Gabriel Bunge, Akedia..., p. 27.

${ }^{8}$ Pr. Prof. Ștefan Alexe, Sfinții Părinți..., p. 267.

${ }^{9}$ Evagrie Ponticul, Scolii la Pilde și Ecclesiast ..., p. 10.

${ }^{10}$ Pr. prof. Dumitru Stăniloae, Viața și scrierile lui Evagrie Ponticul, în Filocalia, vol. I, Humanitas Publisher, București, 1999, p. 49.
} 
the resignation of this protector, he continues to be around patriarch Nectary. This new position and his sound theological knowledge push him towards the gulf of the dogmatic controversies of those times, which he combats through the sermons that were so highly valued by the listeners.

This new context or other reasons ${ }^{11}$ may have determined Evagrius to leave the great Byzantine citadel and head for Jerusalem. This is where he encounters Saint Melanie the Elder who advises him to become a monk on Easter Day of 383 in Rufin's Mount of Olives Monastery. After a short while spent in the Holy City and following a physical distress of which cause remains unknown, he decides to settle down in Egypt and starts his ascetic life under the guidance of the two great Macarius: Macarius of Egypt and Macarius of Alexandria. He spends two years in the Nitrian desert and the remaining of his life in Kellia, the area of hermitage. In a very short time, numerous disciples ${ }^{12}$ are inspired by his improved life and led themselves guided by wise advice originating in an authentic living and feeling of the Gospel of the Savior. This very zeal recommends him for ordination as bishop, as patriarch Theophilus of Alexandria would have wanted. Nevertheless, the offer is constantly rejected by Evagrius who will pursue serving Jesus Christ, as a humble hermit, until he passed into eternity in 399.

\section{THEOLOGICAL AND DOGMATIC THEMES IN EVAGRIUS PONTICUS' WRITINGS}

Following an inventory of Evagrius' writings, patriarch Iustin Moisescu comes to the conclusion that of all the works attributed to the monarch of Pontus, only seven may be deemed as authentic: 1. Practicus or the Monarch; 2. Antirrhetikos; 3. The Gnostikos or To the One who Deserved the Gnosis; 4. Six Hundred Gnostic Issues; 5. To the Monarchs in Monasteries or Assemblies; 6. To the Virgin or the Virgins and 7. Epistles.

Although the writings have an ascetic nature and they mainly focus on the monastic environment, as they target the reader who pursues hesychia ${ }^{13}$, we cannot overlook the use of his teachings to the spiritual life. They are useful to all people who seek redemption, that is the same as getting to know God, namely the gnosis that leads to spiritual contemplation.

In terms of theological and dogmatic norms in Evagrius' works, patriarch Iustin divides them into three main chapters: I. Theology, II. Cosmology and III. Eschatology.

Evragius' theology is organized by patriarch Iustin in 5 subchapters: God, The Holy Trinity, The Father, The Son and The Holy Spirit. In relation to God, Evagrius affirms that "in essence, there is but one God. He may not be defined as the definitions belong to a world that is produced and composed, while God has no beginning and is uncomposed"14. God the Father, the Son and the Holy Spirit forms the Holy Trinity, impossible for the human mind to encompass. The Holy Trinity is not subjected to transformation and does not change. It is made up of three hypostases: the Father, The Son and the Holy Spirit, which means that it is not composed, as it is not a numerical trinity, "but a uniform essence, in full and forever equal to itself" 15 .

\footnotetext{
${ }^{11}$ Palladius mentions an amorous trap laid by a woman from high society, woman whom he escapes by going to Palestine (see Istoria Lausiacă, p. 88).

${ }^{12}$ Among his disciples, patriarch Iustin mentions: Palladius, Saint John Cassian, Heraclides, bishop of Ephesus and writer Rufin.

${ }^{13}$ Isihia - from the Greek $\eta \sigma v \chi i$ í which means "inner peace", the peace of the soul illuminated by the divine grace, which brings inner peace by communion with God.

${ }_{14}^{14}$ Patriarhul Iustin, Evagrie din Pont, Anastasia, 2003, p. 123.

15 Ibidem, p. 126.
} 
On the Person of the Father, Evagrius Ponticus tells us that He has created everything, and $\mathrm{He}$ is the cause of everything and every end. The Son of God is the first and the one born from the Father, through Whom all things were made. For His great love of men, He descended from Heaven and was incarnated as man and took the soul of man. "Being made of material elements, the body of the Savior was created in time, and right after His creation, the body united with God the Word and has been united with Him since then. His body was never subjected to decay after the resurrection from the dead" ${ }^{\prime 16}$. In relation to the last person of the Holy Trinity, the Holy Spirit, Evagrius Ponticus tells us that it is the same as the Father and the Son and is Holy in essence, not by attainment.

Patriarch Iustin Moisescu divides the second chapter into five subthemes: The Creation of the World, the Fall of the Rational Human Beings, The Angels, the People and the Demons. "Creation of the Holy Trinity, the world - all rational beings created, who are all the same by their nature and united with God by grace - was created in time, even though it has been with God's wisdom and His creating power with no beginning", according to his Holiness ${ }^{17}$.

With reference to the creation of the world, Evagrius Ponticus affirms that rational beings (angels, people, demons) have been good and perfect since the beginning, yet not in the meaning of absolute and positive perfection, which is the prerogative of God only. Therefore, Evagrius dares to affirm that rational creatures are sometimes "divine" or even "gods".

Later on in the same chapter, Evagrius of Pontus focuses on the fall of the rational beings, who were happy to coexist in the Holy Trinity. With regards to their fall, Evagrius states that it originates in the evil being introduced into the world, which is "identified with not knowing, which is the exact opposite of knowing God" ${ }^{\prime 18}$.

In Evagrius' view, the Angels are 'beings composed of essence and godliness, who, while moving, drifted apart to a lower extent from unification with God"19.

The demons are the creatures that drifted away from God to the highest extent. They are opposed to angels in all aspects and they seek the perdition of men.

The third category of rational creatures, people are, by their nature, equal to the other ones. In terms of their drifting away from God, they stand right between the angles and the demons. "A first consequence of their fall is the destruction of the unity of their spiritual nature, as well as the disturbance of the natural order of the powers of the soul" 20 .

From the eschatological teachings of Evagrius of Pontus, the patriarch Iustin Moisescu develops themes such as the Last Judgment, the Division of Heaven, or the existence of hell.

As for the Last Judgment, Evagrius Ponticus says that all rational beings lead their right life in line with how deep down they have fallen. "After all beings have settled by the side of good or evil, the right judgment will come. As commanded by the righteous judge, all creatures will regain the bodies within which they lived, bodies which will be instantly turned into spiritual bodies. The creatures therefore renewed shall live in their new bodies until the end of time. Their bodies will not decay just like the body of Christ the Savior" ${ }^{21}$.

\footnotetext{
${ }^{16}$ Ibidem, p. 126.

${ }^{17}$ Ibidem, p. 127.

${ }^{18}$ Ibidem, p. 133.

${ }^{19}$ Ibidem, p. 136.

${ }^{20}$ Ibidem, p. 137.

${ }^{21}$ Ibid, p. 140.
} 
The kingdom of heaven or the paradise, as it is also called, will be the reward of those who were good. This should not be interpreted as a certain place or a certain state that remains unknown to us, but as a state within ourselves. The angels are already in the kingdom of heaven, and this state of happiness is offered to people by God, in harmony with every person's actions. The Hell, just like the kingdom of heaven, is the continuation of life by bad people in this world. Evagrius tells us that the purpose of torturing sinners in hell is purification, and no sinner shall escape hell.

\section{SPIRITUAL LIFE IN EVAGRIUS PONTICUS' VIEW}

Enlarging upon the theme of Christian Life, as one finds it in Evagrius Ponticus' writings, Iustin Moisescu also mentions that his works had a strong influence on the life of Christians in Syria in relation to whom Evagrius may be called "teacher by excellence". This appellation is sufficient for us to understand the impinge of his works on the orthodox mystics until late, in the $14^{\text {th }}$ century. Many of his ideas can be found in works of Saint John Climacus, Saint John of Damascus, Saint Maximus the Confessor or Saint Symeon the New Theologian.

From Evagrius Ponticus' perspective, spiritual life means regaining the state of peaceful soul with which man was endowed by God as early as the creation and which man lost through committing sins. This spiritual undertaking, which is in fact an ascent of the soul up to the supreme happiness - unification with God in three persons, is achieved by exercising one's own will with the help of the divine grace. The will is tested through asceticism, which strengthens the soul and releases it from all influence which may come from the body and which may deviate it from the path of knowledge. In the birth of passions tying the soul to material pleasures, an important role is played by demons as powers through which evil manifests itself in the world.

As every Christian, be they monks or laymen, fights a personal fight against the evil, one understands that there is only one and the same spiritual life, even though, at first sight, laymen and monks do not always use the same means. The demonic works are everywhere, both in the desert and "in the world", and they come to surface in many and various ways. Following the example of Christ, the One who was tempted and stood against the devil using the word of the Scripture, Evagrius provides the ones in need with biblical answers to the thoughts coming from the enemy ${ }^{22}$, thoughts which unrest the soul of the Christian and which the author reduces to eight: greed, lust, love for money, grief, anger, sloth, vainglory and pride. All the other passions originate in these sins.

The ascent up to gaining the kingdom of God is made up of three stages: "making"

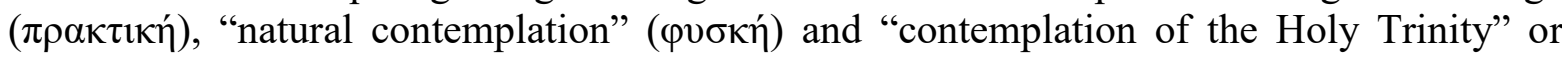
"theology" $(\theta \varepsilon \omega \lambda \sigma \gamma i \alpha)$. The first stage is represented by the war against the passions towards gaining the virtues, the last of which being love which is understood as a passing door to the second stage: natural contemplation. Once the mind deprived of all passions reaches this stage, it perceives the reasons imprinted in the creation in a spiritual way. The next stage is the highest form of contemplation, the one of the Holy Trinity which is also called the absolute happiness.

${ }^{22}$ See Antireticul mare sau replicile impotriva celor opt gânduri, in Ieromonah Gabriel Bunge, Akedia..., pp. $195-208$. 


\section{CONCLUSION}

Analyzing Evagrius Ponticus' writings and given the depth of his theological ideas, one must admit that he is "the most fecund and most characteristic spiritual writer in the desert of Egypt" and, rightfully, "the father of our spiritual literature"23, recognized both in the Eastern and the Western world, through the works of John Cassian. Furthermore, his works facilitated knowing and promoting, on a larger scale and in a much more accessible way, some ideas of two great Church theologians - Origen and Saint Gregory of Nyssa. A characteristic of his work is that his teachings are presented under the form of "predictions", sentences grouped by 100 , as he is the first religious writer who uses this writing style.

In this study, the notable patriarch Iustin Moisescu highlights Evagrius' exceptional ascetic, theological and philosophical background and focuses on the fact that "his works are even nowadays a testimony of his sound theological and philosophical knowledge, on the one hand, and of the great power of discernment of his mind, on the other hand. As early as the years spent in the desert of Pontus, he had started to learn the Christian dogmas and the ancient philosophical principles. In Egypt, he continues to widen his horizon by reading both the works of Origen, which had a decisive impact on his dogmatic or spiritual system, and the works of Saint Basil the Great, Saint Gregory of Nazianzus, the Great Atanasius, Serapion de Thmuis and Clement of Alexandria"24.

By presenting in detail and with a scientific accuracy the life, writings and teachings of Evagrius Ponticus, patriarch Iustin Moisescu enriches the Romanian and universal patristic literature with a work that stirs the interest of both the specialists and the people who are only eager to enhance their understanding of the Byzantine mystics. Analyzing his study, patrologist Iustin Moisescu clarifies Evagrius' important position in the orthodox spirituality and removes all accusations of heresy launched in relation to this great theologian.

\section{REFERENCES}

[1] Filocalia, vol. I, trad. de Pr. Prof. Dr. Dumitru Stăniloae, Humanitas Publishing House, București, 1999

[2] Evagrie Ponticul, Scolii la Pilde și Ecclesiast, trad. de ieromonah Agapie Corbu, Institutul Biblic şi de Misiune Ortodoxă Publishing House, București, 2017

[3] Paladie, Istoria lausiacă, trad. de pr. prof. dr. Dumitru Stăniloae, Institutul Biblic şi de Misiune a Bisericii Ortodoxe Române Publishing House, București, 2007

[4] Alexe, Pr. Prof. Ștefan, Sfințiii Părinți în preocupările Prea Fericitului Patriarh Iustin, în rev. Biserica Ortodoxă Română, Nr. 3-4/1985, pp.

[5] Bunge, Ieromonah Gabriel, Akedia. Plictiseala și terapia ei după avva Evagrie Ponticul, trad. Ioan I. Ică jr., Deisis Publishing House, Sibiu, 1999

[6] Buzescu, Pr. Prof. dr. N. C., Preocupări patristice ale Prea Fericitului Patriarh Iustin, în rev. Mitropolia Olteniei, Nr. 3-4/1980, pp.

[7] Coman, Pr. Prof. Dr. Ioan G., Patrologie, Mănăstirii Dervent Publishing House, 2000

[8] Patriarhul Iustin, Evagrie din Pont, Anastasia Publishing House, 2003.

${ }^{23}$ Ibid., p. 30.

${ }^{24}$ Pr. prof. Ștefan Alexe, Sfinții Părinți..., p. 268. 